\title{
Politically motivated brand rejection is
}

\author{
Özlem Sandıkc1 ${ }^{*}$, Ahmet Ekici ${ }^{1}$ \\ Bilkent University, Faculty of Business Administration, 06800 Ankara, Turkey
}

Received 1 June 2007; received in revised form 1 November 2007; accepted 1 January 2008

\begin{abstract}
This paper introduces the concept of politically motivated brand rejection (PMBR) as an emergent form of anti-consumption behavior. PMBR is the refusal to purchase and/or use a brand on a permanent basis because of its perceived association to a particular political ideology that the consumer opposes. Specifically, the paper discusses three distinct sets of political ideologies that can lead to rejection of certain brands by some consumers. These ideologies include predatory globalization, chauvinistic nationalism, and religious fundamentalism. The target of PMBR can be both local and global brands and consumers who engage in PMBR do not expect any change in marketing practice.
\end{abstract}

(C) 2008 Elsevier Inc. All rights reserved.

Keywords: Anti-consumption; Boycott; Political consumption; Brand rejection; Coca Cola; Turkey

\section{Introduction}

Both anecdotal and scholarly accounts indicate that anticonsumption attitudes and behaviors have become more diversified and widespread. The term anti-consumption spans a wide continuum, ranging from relatively harmless beliefs, such as negative perceptions of fast-food, to violent and illegal behaviors, such as the acts of vandalism and arson targeted at companies such as McDonald's and Nike. As Zavestoski (2002, p. 121) points out some anti-consumption attitudes may simply be a "function of a preference to consume one object over another" whereas more profound types of anti-consumption attitudes involve "a resistance to, distaste of, or even resentment or rejection of, consumption more generally." This research focuses on brand rejection behavior and contributes to the existing literature by offering new insights on why consumers

\footnotetext{
The authors thank Güliz Ger for her valuable comments. The authors gratefully acknowledge the insightful and stimulating comments by the guest editors and reviewers of this article.

* Corresponding author. Tel.: +90 3122901436.

E-mail addresses: sandikci@bilkent.edu.tr (Ö. Sandıkc1), ekici@bilkent.edu.tr (A. Ekici).

${ }^{1}$ Tel.: +90 3122902628 .
}

may intentionally choose not to consume a particular brand beyond product-related reasons.

People can form negative brand attitudes and refrain from using a brand for a variety of reasons. Consumers may boycott a brand because of its overt commercialism, disrespect for human rights or the environment, or involvement in unethical business practices (Friedman, 1985; Micheletti et al., 2003). Consumers may avoid a brand because they feel animosity toward the country from which the brand originates or believe that purchasing foreign-made products is unpatriotic (Klein et al., 1998; Shimp and Sharma, 1987). Alternatively, consumers may choose not to purchase a brand because the brand represents an undesired self or avoidance group that they do not want to identify with (Englis and Solomon, 1995; Hogg and Banister, 2001). They may also refuse brands that are not compatible with their social roles and other products that they already use (Hogg, 1998).

This study contributes to the existing literature by introducing and discussing an emergent form of anti-consumption behavior: politically motivated brand rejection (PMBR). PMBR is the refusal to purchase and/or use a brand on a permanent basis because of its perceived association to a particular political ideology that the consumer is opposed to. Political ideology is a "belief system that explains and justifies a preferred political order for society, either existing or proposed, and offers a 
strategy for its attainment" (Christenson, 1971, p. 5). Ideologies include both those beliefs and values that serve to legitimate and maintain a certain social order and those beliefs and values that challenge the dominant order and advocate social change. Ideologies play an important social role as they provide people with a necessary point of reference for making sense of the world around them.

Ideology also plays an important role in structuring consumer choice (Crockett and Wallendorf, 2004; Kozinets and Handelman, 2004). Movements such as anti-branding/antiglobalization, green/ethical consumption, and voluntary simplicity (Duane, 1981; Klein, 1999) exemplify consumption behaviors that various political and ideological commitments shape. Scholars link the emergence of political consumerism to the shifts in the political landscape, namely globalization, individualization, and postmodernization, and argue that problems triggered by these changes encourage citizens to use their power as consumers to influence policy (Micheletti, 2003). As problems such as environmental destruction, human rights violations, and unfair business practices become issues that states have difficulty controlling and governing, marketplace choice emerges as a new form of political participation through which citizen-consumers can exercise their agency.

However, increasing conservatism, fundamentalism, and nationalism also characterize contemporary political-social environment (Hanson, 2006). The "clash of civilizations" (Huntington, 1996) is a discourse that appears to accentuate cultural, social, and political differences. These political developments may have an impact on the marketplace and may influence consumers' choices. That is, analogous to the environmental and ethical concerns that promote anti-consumption behaviors, concerns over nationalism or fundamentalism can also foster anti-consumption behaviors.

This exploratory study aims to conceptualize and discuss the nature and implications of PMBR. The paper begins with a review of the anti-consumption literature that provides insights on negative brand attitudes and behaviors. Next are a synopsis of the research context and an outline of the research methodology. The findings section discusses three distinct sets of political ideologies that can lead to rejection of certain brands by some consumers. The paper concludes by reviewing the conceptual differences between PMBR and other related anticonsumption behaviors, managerial implications, and future research areas.

\section{Literature review}

Three major areas of research offer insights on why a consumer may choose not to consume a product. These are the literatures on political consumerism, undesired self and image congruency, and organizational disidentification. Two related concepts are brand dislike (Dalli et al., 2005; Dalli et al., 2006) and brand avoidance (Lee and Motion, 2004; Lee and Conroy, 2005; Lee et al., 2009-this issue). However, due to the lack of published research on these topics, during the time when this study on PMBR was conducted, this literature review excludes these topics.

\subsection{Political consumerism}

Political consumerism entails the use of market actions and consumer choice as a political tool (Micheletti, 2003; Micheletti et al., 2003). Micheletti (2003, p.2) suggests that political consumerism "represents actions by people who make choices among producers and products with the goal of changing objectionable institutional or market practices. Their choices are based on attitudes and values regarding issues of justice, fairness, or non-economic issues that concern personal and family well-being and ethical or political assessment of favorable and unfavorable business and government practice." Political consumerism involves both individual and collective actions and can take a negative (boycott) or positive form (buycott). Consumers' awareness of ethical and political issues surrounding the target object, their motivation to change social conditions and business practices, and their regular involvement in this particular form of engagement differentiate political consumers from ordinary consumers (Stolle and Hooghe, 2003; Stolle et al., 2005).

Boycotts constitute one of the most favored forms of political consumerism. Earlier examples of boycotts date back to the eighteenth century (Bayly, 1986; Hochschild, 2006; Witkowski, 1989). A boycott is different from an individual's decision to withhold consumption of a particular product or service because a boycott constitutes an organized, collective, but non-mandatory refusal to consume a good (Friedman, 1985; Kozinets and Handelman, 1988; Sen et al., 2001). Economical, social, and/or ethical reasons can trigger boycotts. Boycotts may aim to alter the targets' unfair business practices (e.g., lowering prices or increasing quality); or, they may aim to force their targets to undertake specific socially responsible and ethical practices (e.g., labor union recognition or elimination of sweatshops). Consumers' perceptions of the likelihood of the boycott's success, their susceptibility to normative social influences, and the cost associated with boycotting influence their decisions to participate in a boycott (Klein et al., 2004; Sen et al., 2001). Boycotts, like many other anti-consumption acts, are relatively short-term reactions and the act of boycotting usually ends immediately after the target of the boycott meets the demands.

\subsection{Undesired self and image congruency}

Consumers formulate their self-concepts and define their social reference groups through what they choose not to consume as much as what they consume (Banister and Hogg, 2001; Englis and Solomon, 1995, 1997; Hogg, 1998; Hogg and Banister, 2001). For example, studies on avoidance groups show that when consumers associate a lifestyle with a social group that they want to avoid, they tend to negatively evaluate consumption constellations that they believe are stereotypical representations of the behavior associated with the avoidance group (Englis and Solomon, 1995, 1997). As Englis and Solomon (1995, p.24) argue, "consumers may eschew purchase, ownership, and use of such products and activities owing to their reluctance to be identified with an avoidance group". 
Similarly, consumers define "not me" by rejecting "anticonstellations" to avoid an association with the corresponding stereotype (Hogg and Michell, 1997; Hogg, 1998). Anti-constellations "represent the complementarity of negative choices across multi-category products" (Hogg, 1998, p.154) and involve two types of negative choices: non choice and anti choice. As Hogg and Michell (1997, p. 62) explain "non choice includes products and services which are simply not bought, often because they are not within the means of the consumer" whereas anti choices "include products and services which are positively not chosen because they are seen as incompatible and inconsistent with the consumer's other consumption choices and preferences." Thus, consumers can reject products that are not in harmony with their private or public selves.

Studies further indicate that "distastes" or the "refusal of tastes" can communicate as much about individuals as that which they opt to consume (Banister and Hogg, 2001; Hogg and Banister, 2001). Distastes or refusal of tastes manifest the "undesired self" (Ogilvie, 1987), an aspect of the negative self that a person is afraid of becoming. Hogg and Banister (2001) show that distastes and dislikes are important factors in how consumers define their identities and the undesired self can be linked to a series of consumption choices that are represented by tastes and distastes. They conceptualize tastes and distastes to be a "direct function of the pursuit of self-congruity and ideal congruity" (Hogg and Banister, 2001, p.77-8) and demonstrate that in order to enhance or support their self-concept, individuals refrain from using products and services that they associate with negative product-user stereotypes.

\subsection{Organizational disidentification}

This emerging stream of research suggests that people can define and enhance their self-concept not only through brands and products that they consume or do not consume but also through the organizations that they identify or disidentify with. Organizational identification refers to "the degree to which a person defines him or herself as having the same attributes that he or she believes defines the organization" (Dutton et al., 1994, p.239). Identification helps a person to preserve his or her selfconcept by developing a connection with the organization. However, Elsbach and Bhattacharya (2001) argue that a sense of separation from the organization can also help maintain selfconcept. The authors define organizational disidentification "as a self-perception based on (1) a cognitive separation between one's identity and one's perception of the identity of an organization, and (2) a negative relational categorization of oneself and the organization" (Elsbach and Bhattacharya, 2001, p.397).

Elsbach and Bhattacharya's (2001) study offers a framework that delineates the indicators, antecedents, and the consequences of organizational disidentification. The antecedents include personal beliefs, values, and experiences, organizational reputation, and the perceived similarities among the organizational members. The authors argue that organizational disidentification may lead individuals to take action by engaging in public criticism or counter-organizational actions. In their follow-up study, Bhattacharya and Elsbach (2002, p.29) focus on "distinguishing between the profiles of people who identify or disidentify with an organization or view it neutrally." Their results indicate that identifiers and disidentifiers differ primarily in terms of actions and personal experience. Whereas personal experience with the organization plays an important role in identification, lack of personal experience is more common in the case of disidentification. On the other hand, both identifiers and disidentifiers engage in public discourse about the organization. However, "identifiers go beyond talking and act on their belief, whereas disidentifiers stop at discourse" (Bhattacharya and Elsbach, 2002, p.34). In other words, organizational disidentification does not necessarily lead to the proposed counter-organizational actions, such as boycotting the organization's products and/or supporting opposing organizations.

In summary, the literature indicates that consumers may refrain from using a particular product or brand as a reflection of their desire to influence business practices and promote what is good for the society overall, or as part of their desire to avoid social groups, roles, and identities that represent the negative self. Non-usage may involve only one brand or a series of products across categories. Consumers can practice non-usage individually or collectively.

\section{Research methodology}

Because of the exploratory nature of this study, the authors used qualitative research methodologies. They collected data in Ankara, Turkey, between March and December 2005. The study employed a multi-stage and multi-method data collection process that included semi-structured and structured interviews using open-ended questions. During the first stage of the datacollection process a senior class of MBA students, who the authors trained in qualitative research techniques, conducted semi-structured interviews with consumers. The goal was to explore whether consumers deliberately refused any brands and products in their consumption choices, and if they did so, to identify the reasons underlying their behavior. In the interviews, the students used a list of questions that the authors developed. The students asked the informants to state any brands or products they deliberately avoided purchasing. After recording their initial responses, the students asked the respondents to explain the reasons for their refusal behavior. The students repeated the probing for each brand and product that the informants mentioned. Finally, the students asked the informants to explain how long they had been engaging in such behavior and whether their refusal was permanent or temporary.

In order to maximize variation in the sample, the authors divided the students into groups and instructed each group to interview three people from a specified age range, gender and education level. A total of 48 informants (half female/half male) representing a wide variety of age and education levels comprised the sample. Analysis of the first stage data indicated that consumers may reject brands and products for a variety of reasons. These include commonly discussed reasons, such as concerns related to the product, to health, to the environment, and to ethics. However, some consumers reported rejecting a 
brand, whether domestic or foreign, because they associated the brand with a particular ideology. The brands most frequently cited as subject to such rejection behavior were Coca Cola and Cola Turka, a Turkish cola brand. One possible explanation for the dominance of these two brands in the data set is the market situation. At the time of the study, the Turkish cola market had been witnessing a fierce competition between the leader Coca Cola and the new local entrant Cola Turka. A prominent Turkish Islamic company marketed Cola Turka and the company engaged in an aggressive launch campaign that drew upon the anti-American sentiment growing among some Turks following the invasion of Iraq.

The second study explored this particular instance of anticonsumption behavior and focused exclusively on Coca Cola and Cola Turka. Under the supervision of the authors, senior undergraduate marketing students collected the data. Each student conducted structured interviews with two consumers, one exclusive Coca Cola drinker and one exclusive Cola Turka drinker. This selection aimed to generate a sample that consisted only of consumers who were loyal to one brand and did not use the other brand. The informant screening process proceeded as follows: when the student identified a potential informant, the student asked the consumer which cola brand(s) s/he consumed. If the respondent mentioned more than one brand or any brand other than Coca Cola and Cola Turka, the student eliminated the candidate from the sample. Next, the student asked the informant whether s/he was an exclusive user; if not, the student eliminated the candidate. Then, the student asked the informant whether s/he would purchase Coca Cola (or Cola Turka) if the brand $\mathrm{s}$ /he was loyal to was unavailable. If the answer was positive, the student eliminated the candidate. Finally, the student asked the informant whether s/he categorically refused to consume foreign products or products that $\mathrm{s} / \mathrm{he}$ associated with any particular country. If the answers to these questions were positive, the student eliminated the candidate.

The students gave a set of open-ended questions to those informants who met the screening criteria and instructed them to fill in their answers. The questions sought to elicit data on consumers' usage and non-usage behavior and on the reasons, and brand and user images of both the preferred and the nonpreferred brand. The informants stated whether they used other brands of Coca Cola and Ülker companies. They also explained whether they used any of the brands that the popular discourse associates with Americanization or the Islamic movement (for the list of topics explored see Table 1).

The sample consisted of a total of 76 informants equally split in terms of gender. The informants were at least high school graduates and differed in terms of age, occupation, and amount of daily cola consumption (detailed informant information is available upon request). The authors conducted a content-analysis of the data. Both authors independently coded the data and identified the underlying categories and themes. They then compared the coded text for similarities and differences in interpretation. They resolved cases of disagreements through subsequent review of the data and discussion of the interpretation. The acronyms $\mathrm{CC}$ and $\mathrm{CT}$ used in the reporting of findings indicate whether the consumer is exclusive Coca Cola or Cola Turka user.

\section{Context}

Turkey is a predominantly Muslim yet secular and democratic country. Although religion has always played an important role in Turkish culture, after the1980s the role of Islam began to change from a personal act of faith to a politically driven expression of identity (Sandikci and Ger, 2002). As Islam gained more prominence in the public sphere, the polarization between the secular elites and the Islamic groups intensified. However, the 1990s also witnessed the emergence of Islamic entrepreneurs, or what is commonly referred to as "green capital" due to the symbolism of the color green in Islamic culture. Benefiting from the incentives provided by proIslamic governments, these small to mid-size establishments gradually developed into big holding companies operating in diverse fields of business including food, fashion, banking, media, and tourism (Demir et al., 2004).

One of the prominent "green capital" companies is the Ülker Group, the largest confectionary, food, and beverage company in Turkey. Ülker was established in 1944 as a small manufacturer of cookies; over the years the company developed into a global firm that now exports its products to over 95 countries (www.Ülker.com.tr/en). Although Ülker has never projected an Islamic image in its marketing communications, the company is well known for its ties to Islamic politics, particularly to Turkey's ruling pro-Islamic Justice and Development Party. In July 2003, Ülker launched a new product called Cola Turka and entered the cola market. Before that, the Coca Cola Company,

Table 1

List of Topics

I- On Brand Used:

- Usage history (the length of time the brand is used; if other brands used previously, why and when the switch happened)

- Usage experience (daily consumption rate; usage times and occasions; activities accompanying usage; people the brand is consumed with)

- Usage reasons (why the brand is preferred)

- Brand associations

- User profiles

- Brand advertising (awareness of the advertisements; opinions and attitudes about the advertisements)

II- On Brand Not Used:

- Trial experience (whether the brand was ever tried)

- Non-usage reasons (why the brand is not preferred)

- Brand associations

- User profiles

- Brand advertising (awareness of the advertisements; opinions and attitudes about the advertisements)

III- General:

- Usage/non-usage of other products/brands of Coca Cola company

- Usage/non-usage of other products/brands of Ülker company

- Usage/non-usage of products/services such as McDonald's, Levi's, Marlboro, Walt Disney Movies, Starbucks

- Usage/non-usage of products/services such as Aytaç, Ihlas, Yimpaş, Sarar, Zaman

- Usage/non-usage of products/services due to environmental and ethical concerns

IV-Demographic data 
who aggressively promoted its brand and enjoyed more than $60 \%$ market share (Thompson, 2005) dominated the Turkish cola market. Pepsi Cola had around $25 \%$ share and did not engage in much marketing communications activity. Cola Turka's entry with significant advertising support signaled a direct attack on Coca Cola.

The Istanbul affiliate of Young and Rubicam produced the Cola Turka launch commercials which featured American actors Chevy Chase and Bob Brown. The commercials took place in New York and conveyed the idea of American people drinking Cola Turka and becoming Turkish. In the first commercial, Chase walks through Times Square as a car full of Turkish men, wrapped in their national flag, drives by celebrating a soccer victory. Perplexed by what he sees, Chase enters a diner where a New Yorker (Bob Brown) in a cowboy hat, sitting at the counter, speaks to him in Turkish after drinking Cola Turka. In the second commercial, Chase returns to his suburban home to discover his wife preparing a traditional Turkish meal for grandparents and children. At dinner everyone drinks Cola Turka and begins singing the Turkish youth anthem, a popular song associated with Turkish national independence. Chase can't resist any more and sips Cola Turka. In the last scene Chase appears with a bushy black moustache and finally becomes "Turkishized."

The first Cola Turka commercial appeared the day after the capture of eleven Turkish soldiers by American troops while they were on a clandestine mission in the Kurdish area of Iraq. This event provoked widespread anger at the United States and worsened Turkish-American relations which had already experienced a crisis a few weeks earlier when the Turkish Parliament refused to allow the United States military passage through Turkey to open a northern front in Iraq. In the wake of the invasion of Iraq and the capture of Turkish soldiers, Cola Turka became a symbol of growing anti-American sentiment among some Turks (Ozkan and Foster, 2005). However, Ülker did not intend Cola Turka to be a fad or niche product; its stated goal was to gain 25 percent of the market. Three months after its launch, Cola Turka captured 20 percent market share; but by mid 2004 its share had dropped to a stable 10 percent (Thompson, 2005).

\section{Findings}

The analysis indicates that informants refrain from drinking Coca Cola or Cola Turka for a number of reasons. These include product-related as well as politically-oriented reasons. Although there are some informants (less than ten percent) who state that they do not consume the other brand because they do not like its taste or perceive the brand as an expensive or cheap alternative, most informants explain their refusal behavior in terms of some politically-oriented reason. Therefore, while acknowledging that product-related reasons can and do lead to non-usage of a particular brand, this article focuses on the politically-oriented reasons for rejection behavior and its implications.

The analysis of the politically-oriented reasons mentioned by the informants indicates that these consumers perceive an association between the brand they reject and a particular po- litical ideology that they personally oppose. Three distinct sets of political ideologies underlie rejection behavior. Some consumers reject a brand that they associate with a hegemonic and imperialistic form of globalization, or what Falk (1999) refers to as "predatory globalization." Consumers can also reject a brand that they associate with chauvinistic nationalism and manipulation of nationalist feelings for financial gains. Finally, some consumers reject a brand that they associate with religious fundamentalism, which they perceive as representing a threat to contemporary lifestyles.

\subsection{Predatory globalization}

According to its critics, globalization is an ideological construct that conceals the negative consequences of an expanding capitalist system (Klein 1999; Mittelman 1996). They argue that globalization is an exploitive process that perpetuates poverty, deepens inequalities, damages working conditions, fragments communities, homogenizes cultures, and destroys the environment. Addressing such cumulative adverse effects, Falk (1999, p.589) coins the term "predatory globalization" and points out that the "ideological and operational aspects of globalization are associated with the way in which transnational market forces dominate the policy scene." Many of the Cola Turka consumers perceive Coca Cola as a symbol of the hegemony of the United States operating under the guise of globalization. Some of them state that they refuse to drink Coca Cola because they consider the brand represents American cultural imperialism:

It is about American imperialism. I think if I drink Coca Cola I am not drinking it by my own will but because I am forced to do so. (74-CT)

It is a symbol of American exploitation that reaches all the corners of the world. (2-CT)

The cultural imperialism thesis asserts that "certain dominant cultures threaten to overwhelm other more vulnerable ones" (Tomlinson, 1999, p.80) particularly through the export of ideas, values, products, and lifestyles. Cultural imperialism, although not exclusively, generally implies the United States. The spread of products and services such as Coca Cola, Levi's, and McDonald's and retail spaces such as shopping malls and Disney-like complexes constitute typical examples of the imperialistic nature of American culture (Barber and Jihad, 1995; Ritzer, 1993). When consumers associate a brand with cultural imperialism, they may experience an assumed coercive relationship between themselves and the brand. However, they also acknowledge that rather than literally forcing them to consume certain brands, imperialism works in subtler ways. As one informant believes, "Coca Cola is the child of America who smiles at our faces while secretly exploiting us" (29-CT). Thus, certain brands gain hegemonic status not because they exercise coercion but because they present themselves as admirable and attractive alternatives to the local brands. Those consumers who are highly critical of American culture regard 
consuming Coca Cola almost as a criminal act, a form of treachery that does nothing but harm to the local culture:

Who drinks it? A servant of American imperialism, somebody who contributes to making societies forget their own cultures and values. Somebody who serves America and American people. Somebody who propagates American culture. In short, somebody who is not one of us, a traitor, drinks Coca Cola. (45-CT)

Traitors drink Coca Cola. Somebody who doesn't really care about concepts like country and nation drinks it. Coca Cola is one of the symbols that reflect the sympathetic face of America to its collaborators. (23-CT)

Such strong opinions about Coca Cola and its consumers indicate that those who reject a particular brand owing to its perceived association to cultural imperialism maintain a strong ideological divide between local and foreign cultures. Rather than internalizing Coca Cola as a status or lifestyle symbol or harmonizing the brand with local traditions and values (e.g., drinking Coca Cola after fasting all day during Ramadan, a behavior that the Coca Cola Company promotes through advertising), these people distance themselves from the brand and refuse to consume Coca Cola altogether.

This finding presents an interesting contrast to the studies that report various instances of consumption hybridization (Ger and Belk, 1996; Howes, 1996). Previous studies show that consumers in the non-West do not simply emulate foreign goods but they adopt them into the local practice and use them in novel and hybrid ways. However, the current study's findings demonstrate that when consumers strongly associate the brand with the hegemonic dominance of the "West", rejection instead of local appropriation or adoption may happen. Moreover, political developments that exacerbate the tensions between East and West may contribute to the refusal of brands that consumers see as symbols of cultural dominance. Indeed, as the quote below shows, the invasion of Iraq has intensified the negative sentiments toward not only the United States but also toward Coca Cola among certain consumers:

When I think of Coca Cola I think of America, Bush, thousands of innocent people who died in Iraq. We emulate everything that is American. But they [Americans] purchase guns with the money they earn from us and then go kill people. Those who drink it would be very cruel people. Like Bush, somebody who is able to brutally kill many people. A harsh, selfish man who does not care about traditions drinks Coca Cola. (41-CT)

Although these consumers reject Coca Cola due to its perceived association with American cultural imperialism, their rejection behavior is distinct from consumer animosity. Consumer animosity refers to anger felt toward a country due to previous or ongoing political, military, economic, or diplomatic events and negatively affects purchase behavior (Klein et al., 1998; Klein, 2002). When consumers feel animosity toward a country they avoid buying goods produced by that country independently of judgments of product quality. In contrast, the informants in this study do not feel animosity toward all American products and report consuming other American products such as Marlboro cigarettes and Walt Disney movies.

In addition to being a symbol of cultural imperialism, consumers may also perceive Coca Cola as a symbol of the economic dominance of the United States. Some informants believe that the form of globalization Coca Cola represents, benefits only the more powerful countries rather than generating wealth for all. As the following quote indicates, the global identity of Coca Cola invokes predominantly negative concepts such as invasion, domination, and manipulation. Such unfavorable perceptions of Coca Cola is reminiscent of those anti-globalization arguments which maintain that the economic and cultural hegemony of advanced capitalist societies, particularly the United States, put developing countries at risk of increasing poverty and growing inequality (Cox, 1997)

When I think of Coca Cola, I think of a tool of invasion, I think of America playing vicious games to dominate the world. I think of globalization. Big corporations dominate the world. Coca Cola is one of their tools. (53-CT)

Consumers who reject Coca Cola also emphasize that the imbalance in the marketing power of global and local brands creates an unfair and restrictive marketplace. One informant complains about the supremacy of Coca Cola at the retail level and argues that the freedom to choose should not be limited because of the hegemonic presence of global brands. Another informant celebrates the emergence of a local alternative to Coca Cola and perceives the brand as a source of national pride:

I associate Coca Cola very strongly with America and its capitalist system. That's why I am against Coca Cola and drink Cola Turka. What really upsets me is that an American cola drink is available everywhere. Our own cola should also be available in cafes and other places. People should have freedom of choice. (39-CT)

It is the most profitable brand in the world. That's why I waited so many years for a Turkish brand to rival it. (25-CT)

Research indicates that organized actions that seek to curtail the negative impact of globalization on the local culture and economy are not very effective (Baughn and Buchanan, 2001; Witkowski, 2005). Government-imposed trade barriers and consumer boycotts tend to have only a limited and temporary effect on the influx of foreign products and popular culture. However, developments in the political-social context may foster much stronger reactionary feelings among certain groups of consumers and, if there is a viable alternative, the brands that consumers associate with predatory globalization may become targets of permanent rejection behavior. 


\subsection{Chauvinistic nationalism}

Research on country of origin indicates that consumers develop stereotyped images of countries and use these images while evaluating products from different origins (Han and Terpstra, 1988). In the absence of other information, country of origin functions as a mental shortcut to decision making; however, when knowledge and familiarity with the product category is high, the use of country of origin tends to decrease (Maheswaran, 1994). Research also shows that consumers sometimes prefer to purchase domestic products even if they are higher priced and lower quality than foreign alternatives. Consumer ethnocentrism underlies such nationalistically motivated consumption behavior. Consumer ethnocentrism refers to the beliefs held by consumers about the appropriateness and morality of purchasing foreign-made products (Shimp and Sharma, 1987). Ethnocentric consumers believe that purchasing foreign products is wrong, not only because such behavior is unpatriotic but also harmful to the economy. The consequences of consumer ethnocentrism include overestimation of the value of domestic products, underestimation of the quality of foreign products, and a moral obligation to buy domestic products.

Contrary to the expectations of the literature on consumer ethnocentrism, the analysis indicates that local consumers can reject a domestic brand because of its strong identification with nationalism. Almost unanimously, those who reject Cola Turka perceive the consumers of Cola Turka as nationalistic and conservative people who resent foreign brands and give importance to using domestic products. However, they decisively disassociate themselves from the type of nationalism that they think Cola Turka represents. Many believe that the brand uses nationalism and people's nationalistic feelings for financial gain:

By claiming to have Turkishized the cola, it abuses people's nationalistic feelings and tries to capture market share from Coca Cola. (44-CC)

It is as if when people drink Cola Turka they become Turkish. It is absurd. Because its taste is bad, they are trying to sell it by using nationalism. (54-CC)

By offering itself as the Turkish version of cola and asserting that, albeit playfully, even American people drink Cola Turka and become Turkish, the brand seeks to position itself as a superior and morally appropriate alternative. However, for those who refuse to drink Cola Turka, this strategy fails to be persuasive because of its chauvinistic orientation.

While nationalism is the expression of belonging to a single, politically and spatially bounded ethnic group (Horowitz, 1985), chauvinistic nationalism involves attitudes and beliefs about national superiority and "stresses the idea that one's own nation is the only entity of self-determination and respect" (Wittrock, 2004, p.13). Chauvinistic nationalism implies a denigration of other nations and "recognizes no constraints in its nation-building methods, even if this means destroying other nations in the process" (Tan, 2002, p.440). Many of the Coca
Cola users believe that the managers of the Ülker Company utilize any means that they believe will help them achieve success in the market place, even if the practice is abusive or unethical. Thus, recognizing no constraints, Ülker takes advantage of the political context that fosters anti-American sentiments in Turkey and attempts to convert nationalistic feelings into cash by offering nothing but an imitation of the real thing:

It is an invention of Ülker to benefit from the anti-American sentiment that exists in Turkey. Somebody who hides behind nationalism. Somebody who loves money, who is imitative. (22-CC)

It is an imitative brand. It tries to portray an anti-American image and use it for financial gain. It is an unsuccessful product used by conservative, nationalistic and anti-American people. (7-CC)

\subsection{Religious fundamentalism}

Research on the impact of religion on consumption indicates that religious affiliation can be a predictor of consumer behavior (Hirschman, 1983; Delener, 1990). Its predictive power, however, varies with perceived religiosity; that is, self-identification with a religion and its values. Religion can also have a more direct negative impact on consumption behavior by prohibiting use of certain products, such as the ban on consuming pork in Islam. The analysis indicates a different type of relationship between religion and consumption. As is the case when chauvinistic expressions of nationalism foster brand rejection behavior, associating a brand with religious fundamentalism may lead to its rejection by some consumers. Almost all of the informants who refuse to consume Cola Turka point at the religious undertones of the brand and/or the parent company and perceive the brand as a symbol of Islamic fundamentalism. They believe that those who consume Cola Turka do so not because of its taste but as an expression of their support for the political ideology that the brand and its parent company advocate:

When I think of Cola Turka I think of Taliban, religious people. Cola Turka is preferred because of what it symbolizes more than because of its taste. (5-CC)

Cola Turka reminds me of religiously fundamentalist people. I think it is about abusing religion. It is because of its association to Ülker. Cola Turka has become a symbol, it is like the headscarf. (48-CC)

It symbolizes green capital. Ülker has a customer base, it has many loyal consumers. But there is a political dimension to that. People drink Cola Turka not because of its taste but because of its mission. Typically religiously fundamentalist people drink it. (60-CC)

The term fundamentalism originally referred to a conservative strain of Protestantism that developed in the United States 
in the late nineteenth and early twentieth centuries. However, as Emerson and Hartman (2006, p.132) note, unlike many contemporary fundamentalist movements, early U.S. Protestant fundamentalism "was not so much a battle with the secular state as it was an intrareligious fight with other U.S. Protestant people and organizations." Since the 1970s, religious fundamentalism has become a growing and worldwide phenomenon that applies to all religions. In its contemporary usage, scholars generally discuss fundamentalism in relation to modernity and secularism. As Almond, Appleby, and Sivan (2003, p.17) explain, fundamentalism is "a discernible pattern of religious militancy by which self-styled 'true believers' attempt to arrest the erosion of religious identity, fortify the borders of the religious community, and create viable alternatives to secular institutions and behaviors."

In Turkey, Islamic fundamentalism gained momentum after the 1980s and indicated an opposition to secularism, one of the defining tenets of the Turkish Republic (Saktanber, 2002). The Turkish state, the army, and the secular public perceive the rise of political Islam as a threat to the very core of the republic. In line with this viewpoint, many consumers who reject Cola Turka believe that the Ülker Company represents radical religious groups whose hidden agenda is to abolish the secular regime in Turkey and throw her back into the dark ages. As the following quotes indicate, these consumers strongly disassociate themselves from Islamic fundamentalism and refrain from consuming Cola Turka. However, what underlies this rejection behavior is not the desire to avoid a social group or social role that represents an anti-ideal self, but the opposition to a political ideology that they believe has the potential to disrupt and change the governance of the society:

When I think of Cola Turka I think of a phony, political, and ethically poor brand. Ülker makes a distinction between 'us' and 'them'. When I say 'us', I mean a radical circle, a religious sect. I don't drink Cola Turka because I am not one of them. (57-CC)

It is a product that is characterized by its religious and Islamic identity. Cola Turka appears as if it has a modern image but because it has Ülker behind it I categorize it as such. It represents the Islamic and conservative worldview. Even though it tries to look like a modern and contemporary brand, there appear to be some hidden truths, political and material interests. I am not exactly sure but it is like they want to push Turkey away from the path of modernity, and make us go backwards. (68-CC)

The mistrust felt toward the Ülker Company is so strong that some of the informants' characterization of Cola Turka and its users take the form of almost conspiracy-driven judgments. For example, several informants mention a relation between Coca Cola and Israel and argue that religiously fundamentalist people prefer Cola Turka because Coca Cola supports Israelis:

It is used by Turks. More accurately by some Turks. Those people don't want to drink Coca Cola because it is owned by the Israelis. I mean they say the money is sent to Israel. People in my social circle are religious people, they always prefer Ülker products. They say Israelis oppress Muslims a lot. They say that when you read the name Coca Cola backwards it looks like 'There is no Mohammed' written in the Arabic script. (54-CC)

Another informant speculates that the Ülker Company fools its customers into thinking that drinking Coca Cola is sinful:

Ülker is a company that competes by abusing religion. It tries to associate people's religious opinions with the brands they consume. I think this is very wrong. Religiously fundamentalist and ignorant people are made to believe that Coca Cola contains certain ingredients which are not allowed to be consumed according to our religion. Because Ülker appears to be a religious company they trust Cola Turka. (76-CC)

Those who reject Cola Turka cite the brand's association to religious fundamentalism as an explanation for their behavior, but those who consume Cola Turka do not mention the brand's or Ülker's religious identity as a reason for their preference. This behavior may be due to the fact that Islam has become a highly political issue in Turkey; thus, people might be refraining from disclosing their supportive political views, providing product-related justifications instead. Alternatively, religious fundamentalism might operate only as a motive for rejection. A definitive answer to this question requires further research.

\section{Discussion}

The findings reported in this paper provide preliminary evidence for politically motivated brand rejection behavior. More specifically, some consumers may reject certain brands if they perceive an association between the brand and a particular political ideology that they personally oppose. PMBR differs from other related forms of brand rejection on several dimensions. First, unlike political consumption, an unexpected change in the market structure rather than objectionable business practices triggers PMBR. Overall, very few informants indicate that they refrain from consuming brands and products because of a company's lack of sensitivity to environmental concerns or its unethical or abusive business practices. Unlike political consumers who participate in boycotts with the goal of pressuring the target company to correct its bad business practices, consumers who engage in PMBR do not expect a change in the market and business practices.

PMBR is also different from the cases in which a consumer chooses not to consume a particular brand or product in order to avoid a negative reference group or an undesired self. Consumers engage in PMBR not because they want to express a personal lifestyle choice or taste but because they oppose to an ideology that they believe has the potential to change the order of society for the worse. Thus, unlike the studies on avoidance groups and undesired self, PMBR does not deal with the concepts of "taste" (as in lifestyle), change in taste (as in change 
in lifestyle), or life transition. Rather, broader social and political concerns underlie PMBR.

PMBR does not involve consumption anti-constellations and does not lead to a set of negative choices across multicategory products. For example, those who reject Coca-Cola for its perceived association with a hegemonic and imperialistic form of globalization do not necessarily refrain from using other American brands that exemplify globalization, such as McDonald's, Levi's, Marlboro, Starbucks, and Walt Disney Movies. Similarly those who reject Cola-Turka for its perceived association with religious fundamentalism may still use other brands that also carry Islamic connotations, such as Aytac (sausages), Ihlas (home appliances), Yimpaș (supermarket), and Sarar (clothing).

Finally, PMBR appears mainly as a brand-specific behavior and does not entail wholesale disidentification with the company that owns the brand under question. For example, those who refuse to consume Cola Turka because of its perceived association with chauvinistic nationalism and/or religious fundamentalism, report occasional or frequent use of other Ülker products. Beside Cola Turka, Ülker produces and markets various other food and beverage items including biscuits, cookies, milk, and chocolates. Similarly, some of those who reject Coca Cola state that they consume other Coca Cola products such as Fanta.

The findings also carry important managerial implications. First, PMBR may happen even if the target institution does not engage in any bad business practice. The findings indicate that consumer's attitude toward an existing brand may change as a result of the changes in the market structure, such as the entry of a new brand. Some of the informants report that, even though they used to drink Coca Cola and liked its taste, they have stopped consuming the product after Cola Turka, a "politically acceptable" brand became available. This observation is also consistent with what Holt, Quelch, and Taylor (2004, p.75) report: "one person in ten worldwide wouldn't buy global brands if given a choice." Thus, what triggers rejection of the Coca Cola brand among some consumers is not a particular objectionable action undertaken by the Coca Cola Company but rather the entry of Cola Turka with a positioning that highlights nationalist sentiments. This result implies that companies can do little to prevent PMBR and, even though they abide with the principles of fair and ethical business practice, they can still be a target of PMBR.

Second, both local and global companies can be a target of PMBR. In Turkey, as in other markets, Coca Cola Company seeks to portray an image of a locally-sensitive global brand in its advertisements. For instance, during the month of Ramadan, the company runs commercials that present Coca Cola as the appropriate drink for the post-fasting dinner, connecting the American brand with a practice of Islam. Cola Turka, on the other hand, tries to position itself as a brand that even the American people consume. Interestingly, however, those who reject Coca Cola due to political reasons regard its localization attempts as phony and still perceive the brand as a symbol of American imperialism. Those who reject Cola Turka due to political reasons, refuse its claim to be a "globally-accepted" brand and criticize the brand for abusing religious and nationalist sentiments.

Third, unlike temporary acts of anti-consumption, PMBR is enduring in nature. Thus, tackling PMBR may become particularly difficult for the target corporations. A company who encounters boycott can solve this problem by either accepting the demands of the protestors or negotiating a compromise with regard to its practices. However, when a brand is subject to PMBR, overturning negative associations can be well beyond the capabilities of the company. Marketing communications efforts can only be of limited help in alleviating the threats that some consumers find in predatory globalization, chauvinistic nationalism, or religious fundamentalism.

Finally, consumers who engage in PMBR may not take full advantage of the offerings in the marketplace. Their decision to reject a certain brand derives from politically-oriented reasons rather than product-related factors. Some Coca Cola consumers stated that they have never tried Cola Turka and they did not intend to do so only because they associated the brand with Islamic fundamentalism. There are others who tried Cola Turka and thought that its taste was comparable to Coca Cola but still reject the brand because of its religious and/or nationalistic connotations. This suggests that PMBR may not only hurt companies but also consumers as those who engage in PMBR might forego consumption of an otherwise acceptable brand.

\subsection{Future research}

Because this research is exploratory in nature, the authors can not generalize the findings to other brands/product categories and contexts. However, the political ideologies discussed in this paper are fundamental concepts and they are likely to apply in other settings. Thus, future research can explore PMBR behavior in other contexts and find out to what extent the political ideologies that this study identified play a role in the rejection of certain brands in different cultures. Furthermore, future work can explore the conceptual differences between PMBR and other anti-consumption behaviors through scale development and measurement studies. Such studies can develop PMBR into a quantitatively measurable construct and assess its construct and discriminant validity.

\section{References}

Almond G, Appleby RS, Sivan E. Strong Religion: The Rise of Fundamentalisms around the World. Chicago: University of Illinois Press; 2003.

Banister Emma N, Hogg Margaret K. Mapping the negative self: From 'so not me'...to 'just not me'. Adv Consum Res 2001;28:242-8.

Barber BR, Jihad Vs. McWorld. New York: Times Books; 1995.

Baughn C Christopher, Buchanan Mark A. Cultural protectionism. Bus Horiz 2001;44:5-15 (November-December)

Bayly Christopher. The origins of Swadeshi (home industry): Cloth and Indian society, 1700-1930. In: Appadurai Arjun, editor. The Social Life of Things: Commodities in Cultural Perspective. Cambridge: Cambridge University Press; 1986. p. 285-321.

Bhattacharya CB, Elsbach Kimberly D. Us versus them: The role of organizational and disidentification in social marketing initiatives. J Public Policy Mark 2002;21(1):26-36. 
Christenson RM. Ideologies and Modern Politics. New York: Dodd, Mead \& Company; 1971.

Cox KR, editor. Spaces of Globalization: Reasserting the Power of the Local. New York: Guildford; 1997.

Crockett David, Wallendorf Melanie. The role of normative political ideology in consumer behavior. J Consum Res 2004;31:511-28 (December).

Dalli Daniele, Gistri Giacomo, Romani Simona. Brand dislike: evidence for qualitative research and scale development. Rejuvenating marketing: contamination, innovation, integration. In: Toroilo G, editor. Proceedings of the 34th Annual Conference of the European; 2005.

Dalli Daniele, Romani Simona, Gistri Giacomo. Brand dislike: representing the negative side of consumer preference. Adv Consum Res 2006;32:680.

Delener Nejdet. The effects of religious factors on perceived risk in durable goods purchase decisions. J Consum Mark 1990;7:27-38 (Summer).

Demir Omer, Acar Mustafa, Toprak Metin. Anatolian tigers or Islamic capital: prospects and challenges. Middle East Stud 2004;40(6):166-88.

Dutton Jane M, Dukerich Janet M, Harquail Celia V. Organizational images and member identification. Adm Sci Q 1994;39:239-63 (June).

Duane Elgin. Voluntary Simplicity. New York: William Morrow and Company; 1981.

Elsbach Kimberly D, Bhattacharya CB. Defining who you are by what you are not: a study of organizational disidentification and the NRA. Organ Sci 2001;12(4):393-413.

Emerson Michael O, Hartman David. The rise of religious fundamentalism. Annu Rev Sociology 2006;32:127-44.

Englis Basil G, Solomon MR. To be or not to be: Lifestyle imagery, reference groups, and the clustering of America. J Advert 1995;24(Spring):13-28.

Englis Basil G, Solomon Michael R. Special session summary: I am not therefore, I am: The role of avoidance products in shaping consumer behavior. Adv Consum Res 1997;24:61-3.

Falk R. Predatory Globalization: A Critique. Cambridge, UK: Polity Press; 1999.

Friedmam Monroe. Consumer boycotts in the United States, 1970-1980: contemporary events in historical perspective. J Consum Aff 1985;19(1): 96-117.

Ger Guliz, Belk Russ. I'd like to buy the world a Coke: consumptionscapes of the 'less affluent world'. J Consum Policy 1996;15(3):229-54.

Han C Min, Terpstra Vern. Country of origin effects for uni-national and binational products. J Int Bus Stud 1988;19(2):235-55.

Hanson EO. Religion and Politics in the International System Today. Cambridge: Cambridge University Press; 2006.

Hirschman Elizabeth C. Religious affiliation and consumption processes: an initial paradigm. Research in Marketing. Greenwich, CT: JAI Press; 1983. p. 131-70.

Hochschild A. Bury the Chains: Prophets and Rebels in the Fight to Free an Empire's Slaves. Boston: Houghton Mifflin; 2006.

Hogg Margaret K. Anti-constellations: Exploring the impact of negation on consumption. J Mark Manag 1998;14(April):133-58.

Hogg Margaret K, Banister Emma N. Dislikes, distastes and the undesired self: Conceptualising and exploring the role of the undesired end state in consumer experience. J Mark Manag 2001;17:73-104.

Hogg Margaret K, Michell Paul CN. Special session summary: Exploring anticonstellations: Content and consensus. Adv Consum Res 1997;24:61-3.

Holt Douglas B, Quelch John A, Taylor Earl L. How global brands compete. Harvard Bus Rev 2004:68-75 (September).

Horowitz DL. Ethnic Groups in Conflict. Berkeley, CA: University of California Press; 1985

Howes D, editor. Cross-Cultural Consumption: Global Markets, Local Realities. London: Routledge; 1996.

Huntington SP. The Clash of Civilizations and the Remaking of World Order. New York: Touchstone; 1996.

Klein Jill G. Us versus them, or us versus everyone? Delineating consumer aversion to foreign goods. J Int Bus Stud 2002;33(2):345-63.

Klein Jill G, Smith N Craig, John Andrew. Why we boycott: consumer motivations for boycott participation. J Mark 2004;68:92-109 (July).

Klein N. No Logo: Taking Aim at the Brand Bullies. New York: Picador; 1999.
Klein Jill G, Ettenson E Richard, Morris Marlene D. of foreign product purchase: an empirical test in the People's Republic of China. J Mark 1998;62(1):89-100.

Kozinets Robert V, Handelman Jay M. Adversaries of consumption: Consumer movements, activism, and ideology. J Consum Res 2004;31:691-704 (December).

Kozinets Robert V, Handelman Jay M. Ensouling Consumption: A Netnographic Exploration of Boycotting Behavior. In: Alba Joseph, Hutchinson Wesley, editors. Advances in Consumer Research, vol. 25. Provo, UT: Association for Consumer Research; 1988. p. 475-80.

Lee Michael SW, Conroy Denise. Brand avoidance: the brand as a market-based liability. Presented at EMAC: Rejuvenating Marketing; 2005.

Lee Michael SW, Motion Judith. Brand avoidance and genetically modification: is there a relationship? Presented at the ANZMAC, Wellington, New Zealand; 2004.

Lee Michael SW, Motion Judith, Conroy Denise. Anti-consumption and brand avoidance. J Bus Res 2009;62:169-80 (this issue); [Special Issue on Anti consumption]. doi:10.1016/j.jbusres.2008.01.024.

Maheswaran Durairaj. Country of origin as stereotype. J Consum Res 1994;21(2): 354-64.

Micheletti M. Political Virtue and Shopping. New York: Palgrave Macmillan; 2003.

Micheletti M, Follesdal A, Stolle D. Politics, Products, and Markets: Exploring Political Consumerism Past and Present. New Brunwinsk, NJ: Transaction Presss; 2003.

Mittelman J, editor. Globalization: Critical Reflections. Boulder, CO: Rienner; 1996.

Ogilvie Daniel M. The undesired self: A neglected variable in personality research. J Pers and Soc Psychol 1987;52(2):379-85.

Ozkan Derya, Foster Robert J. Consumer citizenship, nationalism, and neoliberal globalization in Turkey: the advertising launch of Cola Turka. Advert Soc Rev 2005;6(3):1-34.

Ritzer G. The McDonaldization of Society. Thousand Oaks, CA: Pine Forge; 1993.

Saktanber A. Living Islam: Women, Religion and the Politicization of Culture in Turkey. London: I.B. Tauris; 2002.

Sandikci Ozlem, Ger Guliz. In-between modernities and postmodernities: Investigating Turkish consumptionscape. Adv Consum Res 2002;29:465-70.

Sen Sankar, Gurhan-Canli Zeynep, Morwitz Vicki G. Withholding consumption: a social dilemma perspective on consumer boycotts. J Consum Res 2001;38:399-417 (December).

Shimp Terence, Sharma Subash. Consumer ethnocentrism: construction and validation of the CETSCALE. J Mark Res 1987;24:280-9.

Stolle Dietlind, Hooghe Marc. Consumers as political participants? Shifts in political action repertoires in Western societies. In: Micheletti M, Follesdal A, Stolle D, editors. Politics, Products, and Markets: Exploring Political Consumerism Past and Present. New Brunswick, NJ: Transaction Presss; 2003. p. 265-88.

Stolle Dietlind, Hooghe Marc, Micheletti Michele. Politics in the supermarket: political consumerism as a form of political participation. Int Polit Sci Rev 2005;26(3):245-69.

Tan Kok-Chor. Liberal nationalism and cosmopolitan justice. Ethical Theory Moral Pract 2002;5:440-1 (December).

Thompson D. Marketing Management in Turkey: Cases and Challenges. Ankara: Gazi Kitabevi; 2005.

Tomlinson J. Globalization and Culture. Chicago: University of Chicago Press; 1999.

Witkowski Terence H. Antiglobal challenges to marketing in developing countries: exploring the ideological divide. J Public Policy Mark 2005;24(1): $7-23$.

Witkowski Terrence H. Colonial consumers in revolt: Buyer values and behavior during the nonimportation movement, 1764-1776. J Consum Res 1989;16:216-26 (September).

Wittrock Jeremy. Global government through global economics: a practical guide to a just world government. New Thinking 2004:13-23 (Winter).

Zavestoski Stephen. Guest editorial: Anticonsumption attitudes. Psychol Mark 2002;19:121-6 (February). 